\title{
A Survey of ICT Competencies among Students in Teacher Preparation Programmes at the University of Benin, Benin City, Nigeria
}

\author{
R. B. Danner \\ Department of Educational Psychology and Curriculum Studies, \\ University of Benin, Benin City, Edo State, Nigeria \\ gdanner58@gmail.com \\ C. O. A. Pessu \\ Girls' Model Secondary School Ewvreni, \\ Delta State, Nigeria \\ eworitseakus@yahoo.com \\ Executive Summary
}

Today's fast-paced world is becoming increasingly characterized by technology driven communication, which has transformed the world into a large global connected community with everincreasing outreach of information and communication technology (ICT). Technology plays an increasingly important role in people's lives, and it is envisaged that technological literacy will soon become a functional requirement for people's work, social, and even personal lives. For both social and economic reasons students will need computer and communication technology skills if they are to live successfully in a knowledge-based society. The purpose of this study is to examine the ICT usage habits and the self-assessed ICT competencies possessed by undergraduate students in teacher preparation programmes in the University of Benin. A second important issue that was addressed was whether there were significant differences in the perceived ICT competency among students according to demographic and study related factors. Thus, the paper's central research objectives are:

- To examine the ICT usage habits of students in teacher preparation programmes.

- To examine the self-assessed ICT skills' competencies possessed by students in teacher preparation programmes.

- To determine whether there were significant differences in perceived ICT competencies among students in teacher preparation programmes according to demographic and study

Material published as part of this publication, either on-line or in print, is copyrighted by the Informing Science Institute. Permission to make digital or paper copy of part or all of these works for personal or classroom use is granted without fee provided that the copies are not made or distributed for profit or commercial advantage AND that copies 1) bear this notice in full and 2) give the full citation on the first page. It is permissible to abstract these works so long as credit is given. To copy in all other cases or to republish or to post on a server or to redistribute to lists requires specific permission and payment of a fee. Contact Publisher@,InformingScience.org to request redistribution permission. related factors (gender, and type of computer training).

A descriptive survey was adopted and the target population was all students in levels 200, 300, and 400 of the faculty of education, University of Benin. The instrument for data collection was a questionnaire adapted from Bassey, Akuegwu, Udida, Ntukidem, and Ekabua (2007). The results show that: 
- Students' ICT usage was low, particularly the use of internet and email.

- The respondents perceived themselves to be good in word processing and file navigation, moderate in Internet browsing and emailing. Only two percent $(2 \%)$ of the respondents perceived themselves to be competent in PowerPoint with about seventy percent $(70 \%)$ having no capability at all.

- There was no significant difference in the perceived competency among students according to gender and academic year/level. However, there was significant difference in the perceived competency among students according to the type of computer training, with those with formal computer training perceiving themselves to be most competent in ICT skills.

- From the findings, the lack of access to computers and Internet connectivity within the faculty present a serious issue affecting staff and students' use of ICT applications.

It is therefore recommended that government should make funds available for the provision of ICT infrastructure in tertiary institutions in the country. Also special funds should be set aside to revamp the e-learning centres at the faculty level for students and faculty/staff use.

Keywords: ICT skills, ICT competencies, technologies, pedagogy, teacher preparation programmes

\section{Introduction}

Today's fast-paced world is becoming increasingly characterized by technology-driven communication, which has transformed the world into a large global connected community with everincreasing outreach of information and communication technology (ICT). ICT refers to the range of technologies that are applied in the process of collecting, storing, editing, retrieving, and transfer of information in various forms (Olakulehin, 2007). The Federal Ministry of Education, Nigeria (2010) defines ICT as encompassing all equipment and tools (inclusive of traditional technologies of radio, video, and television to the newer technologies of computers, hardware, firmware, etc.), as well as the methods, practices, processes, procedures, concepts, and principles that come into play in the conduct of the information and communication activities. The importance of technology in people's lives is unimaginable and it is envisaged that technological literacy will soon become a functional requirement for people's work, social, and even personal lives. For both social and economic reasons students will need computer and communication technology skills to live successfully in a knowledge-based society.

Education is the first and best key area for ICT applications. ICT is often perceived as a catalyst for change, change in teaching styles, and change in learning approaches and in access to information (Watson, 2005). ICTs can help by providing alternative possibilities for education (Casal, 2007). Use of different information communication technologies has become inevitable for students in learning. By using modern information communication technologies, students can retrieve required information within a short time. They can access and disseminate electronic information such as e-books and e-journals and can improve their learning by using different modern ICTs in form of wireless networks, internet, search engines, databases, websites, and web 2.0 technologies. Teachers are a vital link in the education chain, and for education to truly respond to the needs of 21 st century, they must play a central role in leveraging technology, and in particular, using new and old Information and Communication Technology (ICT) devices in teaching and learning. What kind of skills will teachers need to acquire in order to be effective in an ICT based learning environment? This study will address this issue by highlighting the experiences of teachers using ICT in Nigeria, and offering some further examples of established ICT teaching and learning applications in other developing and developed countries. However, how prepared 
are the teachers in Nigerian classrooms to deliver 21st century education? The challenge in Nigeria today is not only shortage in the availability of teachers who are ICT-competent, but the need to move from learning to use ICT to using ICT to learn.

There is a need for capacity building to improve and update the quality of the existing teaching force, and also to ensure that teacher education programmes integrate content, pedagogy, and technology (Hughes, 2005; Koehler, Mishra, \& Yahya, 2007). The need for training in the use of ICT applications for teachers has been given top priority by government in the developed world. For instance, all British teachers were expected to have undergone training in the use of ICT by 2002. Teachers were equally supported in the purchase of personal home computers. Through these initiatives it is envisaged that many more teachers will be encouraged to explore the possibilities of ICT and increase their confidence in the use of computers (Department for Education and Employment (DfEE), (2000). The use of ICT in teacher education has been widely studied and documented especially the positive influence of ICT in teacher education (Kay, 2006; Murray, Nuttall \& Mitchell, 2008), the use of ICT as instructional tool (Murray et al., 2008; Ryan \& Scott, 2008). Very few studies have been carried out in Nigeria on the use of ICT in education (Jegede, 2008; Ololube, 2007). These studies investigated attitude and competence in the use of computers by academic and non-academic staff in Nigerian higher institutions.

The purpose of the present study was to analyze the pattern of ICT usage habits and perceived competency possessed by undergraduate students in teacher preparation programmes in the University of Benin. Another important issue that was addressed was whether there were significant differences in the perceived ICT competency among students according to demographic and study related factors. Thus, the paper's central research objectives are:

- To describe the ICT usage habits of students in teacher preparation programmes.

- To examine the perceived ICT competencies of students in teacher preparation programmes.

- To determine whether there were significant differences in perceived ICT competencies among students in teacher preparation programmes according to demographic and study related factors (gender, academic year/level and type of computer training).

\section{Literature Review}

\section{Use of ICT in Higher Education}

Today, a great number of experiences with educational technology in higher education exist worldwide, especially in the developed world. This has resulted in new opportunities in the integration of pedagogical and technological resources, which has enlarged flexibility across the learning process. It has equally improved the communication between lecturers and students and the interaction between different educational resources. Oliver (2002) asserts that the use of ICT in higher education enhances student-centered learning.

Within higher education, one of the major teaching challenges has always been helping students to bridge the gap between knowledge and real life practice. This is especially important in applied academic disciplines such as education where professional knowledge is constantly being renewed and recreated through real practice (Cheetham \& Chivers, 2001). The National Policy on ICT in Education and Framework launched in 2010 presents a holistic and broad vision for ICT integration in the education sector in Nigeria. This policy moves beyond a basic technology literacy approach. Rather, it focuses on leveraging technology to transform the roles of the teacher and the learner in the classroom. It has been widely acclaimed that for Nigeria's vision 20:2020 (the economic blueprint aimed at placing Nigeria among the biggest 20 economies in the world 
by 2020) to be achieved, education, especially teacher development, will play a key role and ICT equally so.

Teacher development is clearly required to prepare teachers with ICT skills to equip students with the kinds of critical skills needed if they, as members of the society, are to contribute meaningfully in the country's future development. All teachers need to be familiar with ICT applications and competent in the use of ICT applications. White (2003) recommends that teachers need to experience online learning as part of their professional development. The National Universities Commission (NUC) has worked assiduously to lay the foundation for ICT integration in higher institutions through investment in ICT infrastructure, management information systems, e-mail access, and library information services. There have been essentially three kinds of ICT infrastructural provisions in Nigerian tertiary institutions. These are:

- Local initiatives; conceived and developed using local resources

- Corporate initiatives; corporate organizations such as Cisco and Microsoft

- International partnership initiatives; for instance the NetTel@Africa telecommunications management post graduate programme project sponsored by the Nigerian Communications Commission in partnership with regional stakeholders united in their desire to increase the capacity of African ICT sector.

In line with the National Information Technology Development Agency's (NITDA) mandate of Private Public Partnership (PPP) arrangement, the University of Benin, in 2002, went into partnership with Broadband Technology, an IT firm based in Lagos. This led to the establishment of U. B. Technologies, which was specifically, to provide;

- Internet services for students and staff,

- Training on ICT use for students and staff, and

- Computer services at a reduced rate.

However, although, the University of Benin has adopted and customized the Uniben.waeup.org portal (This is the Student Registration Portal [SRP] of the University of Benin, which is part of the West African e-University Project (WAeUP) to improve productivity and promote efficient record-keeping to enhance administrative services.), the use of ICT applications in the teaching and learning process has not really taken-off in the university.

\section{ICT Skills and Competencies}

Regardless of the quantity and quality of technology available in classrooms, the key to how ICTs are used is the teacher; therefore, teachers must have the competence and the right attitude towards technology (Kadel, 2005). Competence is defined as the ability to combine and apply relevant attributes to particular tasks in particular contexts. These attributes include high levels of knowledge, values, skill, personal dispositions, sensitivities and capabilities, and the ability to put those combinations into practice in an appropriate way (Commonwealth Department of Education, Science and Training, 2002). An ICT competency describes what a teacher should know to be able to use technology in his/her professional practice.

Kirschner and Woperies (2003) highlighted some major ICT competencies teachers require. These include competency in:

- making personal use of ICT;

- mastery of a range of educational paradigms that make use of ICT;

- making use of ICT as minds tools; 
- using ICT as tool for teaching,

- mastering a range of assessment paradigms which involves use of ICT; and

- understanding the policy dimensions of the use of ICT for teaching and learning.

Similarly, Marija and Palmira (2007) classified ICT competencies into two: basic and educational ICT competence. In Nigeria, higher education institutions still have a long way to make optimal use of ICT in the learning process as the ICT competencies of the majority of teachers at this lev$\mathrm{el}$ is at the basic level, if they have any at all.

At the global level UNESCO designed a competency framework for teachers (ICT-CFT), which was launched in 2008 to help educational policy-makers and curriculum developers identify the skills teachers need to harness technology in education (UNESCO, 2008). The Competency Standards were developed in cooperation with Cisco, Intel, and Microsoft, as well as the International Society for Technology in Education (ISTE). The framework was created by crossing three approaches to ICT integration in education (Technology Literacy, Knowledge Deepening, and Knowledge Creation) with the six components of the educational system (Policy \& Vision, Curriculum \& Assessment, Pedagogy, ICT, Organization \& Administration, and Teacher Professional Development). This is shown in Figure 1.

\begin{tabular}{|c|c|c|c|}
\hline POLICY AND VISION & $\begin{array}{l}\text { TECHNOLOGY } \\
\text { LITERACY }\end{array}$ & $\begin{array}{l}\text { KNOWLEDGE } \\
\text { DEEPENING }\end{array}$ & $\begin{array}{l}\text { KNOWLEDGE } \\
\text { CREATION }\end{array}$ \\
\hline $\begin{array}{l}\text { CURRICULUM } \\
\text { AND ASSESSMENT }\end{array}$ & $\begin{array}{c}\text { BASIC } \\
\text { KNOWLEDGE }\end{array}$ & $\begin{array}{l}\text { KNOWLEDGE } \\
\text { APPLICATION }\end{array}$ & $\begin{array}{l}\text { 21st CENTURY } \\
\text { SKILLS }\end{array}$ \\
\hline PEDAGOGY & $\begin{array}{l}\text { INTERGRATE } \\
\text { TECHNOLOGY }\end{array}$ & $\begin{array}{l}\text { COMPLEX PROBLEM } \\
\text { SOLVING }\end{array}$ & $\begin{array}{l}\text { SELF } \\
\text { MANAGEMENT }\end{array}$ \\
\hline ICT & $\begin{array}{l}\text { BASIC } \\
\text { TOOLS }\end{array}$ & $\begin{array}{l}\text { COMPLEX } \\
\text { TOOLS }\end{array}$ & $\begin{array}{l}\text { PERVASIVE } \\
\text { TOOLS }\end{array}$ \\
\hline $\begin{array}{l}\text { ORGANIZATION } \\
\text { \& ADMINISTRATION }\end{array}$ & $\begin{array}{l}\text { STANDARD } \\
\text { CLASSROOM }\end{array}$ & $\begin{array}{l}\text { COLLABORATIVE } \\
\text { GROUPS }\end{array}$ & $\begin{array}{l}\text { LEARNING } \\
\text { ORGANIZATIONS }\end{array}$ \\
\hline $\begin{array}{l}\text { TEACHER PROFESSIONAL } \\
\text { DEVELOPMENT }\end{array}$ & $\begin{array}{l}\text { DIGITAL } \\
\text { LITERACY }\end{array}$ & $\begin{array}{l}\text { MANAGE } \\
\text { AND GUIDE }\end{array}$ & $\begin{array}{l}\text { TEACHER AS } \\
\text { MODEL LEARNER }\end{array}$ \\
\hline
\end{tabular}

Figure 1: UNESCO ICT Competency Framework for Teachers Framework, Source: UNESCO, 2008

The guidelines recommend that the identification of ICT competencies for teachers should be based on a clear understanding of a country's overall approach to ICT use in education. Different countries could adopt any one combination of three approaches:

i) to develop a technology-literate workforce to enhance national economic productivity and competitiveness;

ii) to develop knowledge workers, or individuals who can apply knowledge to add value to the economy and society; and

iii) to develop innovators and knowledge creators for the knowledge society.

Lee (1997) found that a great number of students in teacher preparation programmes were not equipped with basic computer operational skills. Ozoemelem's (2010) study revealed that there is a low level of skillfulness in the use of ICT among students of Nigerian universities. Similarly, Yusuf (2005) reported that teachers in Nigerian secondary schools are not competent in basic computer operations and in the use of generic software. If teachers are expected to integrate ICT into the school curriculum, preparations must be made at the pre-service teacher education level. Teacher preparation programmes should focus on the need for student-teachers to have ICT skills for their own use, in the preparation of materials for teaching and learning activities; the need to facilitate the direct use of ICT in students' learning activities within the classroom situation; and 
the need for teachers to develop in their students a critical awareness of ICT applications and the social implications (Robbins, 1998).

\section{Gender and ICT Competencies}

In recent years, the gender gap issue in ICT has been the subject of many studies both internationally and locally. Studies have established that females tend to be less interested in computers than males and use them less often in their spare time (Schaumburg, 2001). In addition, studies have established that girls are less confident than boys in their computer skills, and that boys scored better than girls in computer related knowledge and skills. In addition, the three computer related occupations (computer scientists, computer engineers and system analysts, and computer science and engineering) are the top career choices for boys (Derbyshire, 2003). Bebetsos and Antoniou's (2008) and Kadel's (2005) studies also found that females have negative attitudes towards computers; as a result they are often less computer literate than males. Sefyrin (2005) asserted that competence in ICT could be seen as a question of interest in ICT, where men are more interested in ICT then women.

Many studies show the existence of significant gender differences in ICT competencies among students. Oliver's (1993) study, a replication of an earlier (1985) study, assessed gender differences in ICTs skills among upper primary and lower secondary school students in a city school district in Western Australia. The study revealed significant gender differences among primary school pupils. They further observed that gender differences that were observed among primary school pupils in the 1985 study were still evident in 1991. On the other hand, fewer gender differences were evident among the secondary school students in 1991 compared to what was observed in 1985. In another study, which focused on gender differences in specific areas of computer competency, Rajagopal and Bojin's (2003) found that there were gender differences among male and female college and university students. Their study revealed that 12 percent of male students and 3 percent of female students declared their skills in creating and editing Web page as excellent whereas 35 percent of the male students and 68 percent of the female students reported that they do not have any knowledge in this area. However, in word processing, a clear majority of male, 59 percent and 46 percent of the female students declared their skill as excellent, while 2 percent of the males and 6 percent of the female students said that they have no skill at all. This result is at variance with the common stereotype of women as typist if we were to equate word processing with word processing, a field where women have dominated.

Research by Meelissen (2005) showed that girls seem to have a lower self-efficacy compared to boys especially in more complicated computer tasks. Meelissen's (2005) study of grade five students revealed that regardless of their gender the students could perform most of the common computer tasks such as copying text and saving documents, word processing, or using a draw programme. For less common and more advanced computer skills, such as sending an attachment via an e-mail, forwarding an e-mail, and downloading programs or documents from the Internet, boys showed more self-efficacy than girls. Research done by TengkuFaekah (2005) showed that form four male students in the Kubang Pasu district of Kedah, a northern state in Malaysia, have higher perceived ICT competency than their female counterparts. However, activities such as handling computer hardware and performing computer maintenance are still dominated by males (Atan, Azli, Rahman \& Idrus, 2002). From the review of studies above, it appears that the evidence for specific gender differences in ICT competency is inconclusive although there is a widespread belief that computers and the Internet are male-dominated technologies. It would, therefore, be interesting to find out how gender affects the perceived ICT competencies of undergraduate students in teacher preparation programmes at the University of Benin, Benin City, Nigeria, especially now that ICT is seen as not only crucial for the teaching and learning process but also for professional advancement. 


\section{Computer Training and ICT Competencies}

The literature suggests that lack of adequate training and experience is one of the main factors why teachers do not use technology in their teaching. This also results in teachers' negative attitude towards computer and technology. In addition, lack of confidence leads to reluctance to use computers by teachers (Kumar \& Kumar, 2003). Another problem has been the impact of the lack of training on the integration of ICT into teacher preparation programmes in Nigeria. Training focus repeatedly targets digital literacy with little pedagogical content. Many training institutions have recognized the need for the adoption of ICT standards and its inclusion in the Nigeria teacher education curriculum (Jegede, 2009). The use of ICT in coursework is based on teachers' own initiative as there is no policy or curriculum requirement to use ICT as a tool for teaching.

It becomes imperative that students should be equipped with digital literacy competencies in order to exploit information resources that the electronic age produces. School leavers may not possess the necessary computer skills for their university education although they have been using electronic devices frequently (Nash, 2009). In fact, there is an urgent need for ICT training to be given to fresh university students in order to obtain successful learning outcomes from the use of ICT and to satisfy the needs of their future employers. The most important ICT training needs should include skills development to assist ICT teaching and learning approaches for subject specific areas of specialization; maintenance training; research oriented training on ICT use for data analysis - numerical data; spread sheets; and programmes.

\section{Methodology}

\section{Research Design}

In this study the descriptive survey method was used to investigate ICT usage habits, perceived ICT competency, and related issues of undergraduate students in teacher preparation programmes. A descriptive survey method allows the researcher to pose a series of questions to willing participants, summarize their responses with percentages, frequency counts, or more rigorous statistics, and draw inferences about a particular population from the responses of the sample.

\section{Population and Sample for the Study}

The target population for this study consists of all undergraduate students in teacher preparation programmes in the five departments in the faculty of education in the University of Benin. From this population a sample of 100 undergraduate students was drawn from students in 200, 300 and 400 levels. Students in 100 level were not involved as the survey was carried out during the first week of the semester when first year students were just registering for the new session. All undergraduate students in the university are expected to enroll for CSC110 - Introduction to Computer - during the first semester of 100 level. Students' access to computers in the school is very limited. For teachers, this lack of access gives them no choice other than to teach the course, CSC110, in a theoretical format and, as such, a majority of the students who have computer training have done so at their personal expense. This is sad for, while some university communities in some countries enjoy free or inexpensive ICT facilities especially Internet access, students and faculty/staff in Nigeria must pay for time spent accessing the Internet, whether at a cyber café or in the library (although the library offers a discount).

\section{Research Instrument}

The only instrument for the study was a survey questionnaire: Students ICT Usage and Perceived Competencies Inventory (S-ICT-UPCI) adapted from Bassey et al. (2007). The S-ICT-UPCI questionnaire was structured into three sections. Section A elicited demographic details such as 
department, gender, age, and academic level of the respondents. Section B examined ICT usage habits of respondents. Section $\mathrm{C}$ required the respondents to rate their perceived ICT competencies. It was a 5-point Likert items on ICT knowledge and skills adapted from the Western Australian Guide (2003). The reliability of the instrument was calculated using the Cronbach alpha formula. Reliability coefficients were calculated separately for section B and each of the five subscales in section C. The reliability coefficient of section B was 0.72 . The reliability coefficients in each of the five sub-scales were; 0.74 for File Navigator, 0.73 for Word Processing, 0.72 for Email, 0.72 for Internet, and 0.65 for Presentation Software. Descriptive statistics (frequencies, percentages, crosstabs, and ANOVA) were employed in the analysis of data using the Statistical Package for Social Sciences (SPSS) version 16.0.

\section{Results}

The research findings are presented in three sub-sections corresponding to the three research questions outlined earlier in the paper. Table 1 presents the demographic profile of the respondents. As revealed in Table 1, the distribution of respondents in the various departments was $21 \%$ for ADE, 19\% for EPCS, $20 \%$ each for ESAM, HEK and VTE. The majority of the respondents, fifty nine percent (59\%), were females. This is in line with the general statistics on the prevalence of females in teacher education programmes and within the profession itself where approximately seventy five percent (75\%) of all teachers are women (American Association of University Women [AAUW], 2004). Respondents' age range fell within the 21-25 year bracket. This age bracket was the highest, representing fifty six percent (56\%). Mature students, those in the above 30 years group, were only three percent (3\%). Respondents in the 400 level were highest with forty nine percent (49\%), followed by 300 level with twenty seven percent (27\%) and lastly 200 level with twenty four percent (24\%).

Table 1: Demographic Profile of Respondents

\begin{tabular}{lcc}
\hline & $\mathbf{n}$ & $\mathbf{\%}$ \\
\hline Department: & & \\
Adult and Non-formal Education (ADE) & 21 & $21 \%$ \\
Educational Psychology and Curriculum Studies (EPCS) & 19 & $19 \%$ \\
Educational Studies and Management (ESM) & 20 & $20 \%$ \\
Health, Environmental and Kinetics (HEK) & 20 & $20 \%$ \\
Vocational and Technical Education (VTE) & 20 & $20 \%$ \\
\hline Gender: & & \\
Male & 41 & $41 \%$ \\
Female & 59 & $59 \%$ \\
\hline Age: & & \\
$\mathbf{1 6}-\mathbf{2 0}$ years & 26 & $26 \%$ \\
$\mathbf{2 1}-\mathbf{2 5}$ years & 56 & $56 \%$ \\
$\mathbf{2 6}-\mathbf{3 0}$ years & 15 & $15 \%$ \\
$\mathbf{3 0}$ years and above & 3 & $3 \%$ \\
\hline Academic Level: & & \\
$\mathbf{2 0 0}$ Level & 24 & $24 \%$ \\
$\mathbf{3 0 0}$ Level & 27 & $27 \%$ \\
$\mathbf{4 0 0}$ Level & 49 & $49 \%$ \\
\hline
\end{tabular}




\section{Students' ICT Usage Habits}

Table 2 provides a descriptive profile of the respondents' ICT usage habits. The results indicate that $81 \%$ of the students were computer literate while 19 percent were not. Of the eighty one percent $(81 \%)$ of the respondents who were computer literate, fifty one percent $(51 \%)$ of them had non-formal computer instruction/training; they picked up computer usage from friends, family, and constant use of the computer. Thirty percent $(30 \%)$ of the respondents got some form of formal computer instruction/training from private computer schools. None of the respondents had any approved certificate in computer studies. Further analysis of the data revealed that eighty five percent $(85 \%)$ of the respondents had access to the computer at Internet cafes/business centres with only fifteen percent $(15 \%)$ having access to computers in their homes.

Table 2 shows that fifteen percent (15\%) of the respondents who are computer literate have no access to the Internet. Similarly, on the rate of Internet usage, approximately nineteen percent $(19 \%)$ use the Internet on a daily basis, twenty eight percent $(28 \%)$ used it several times a week, while thirty eight percent (38\%) used it at least once a week. For emailing, only six percent $(6 \%)$ use it on a daily basis, twenty four percent (24\%) use it weekly, twenty percent $(20 \%)$ use it monthly, sixteen percent (16\%) use it a few times a year, while thirty three percent $(33 \%)$ have never used it.

Table 2: Descriptive Profile of Respondents' ICT Usage Habits

\begin{tabular}{|c|c|c|}
\hline & $\mathrm{n}$ & $\%$ \\
\hline $\begin{array}{l}\text { Computer Literate: } \\
\text { Yes } \\
\text { No }\end{array}$ & $\begin{array}{l}81 \\
19\end{array}$ & $\begin{array}{l}81 \% \\
19 \%\end{array}$ \\
\hline $\begin{array}{l}\text { Computer Training: } \\
\text { Formal } \\
\text { Non-formal } \\
\text { None }\end{array}$ & $\begin{array}{l}30 \\
51 \\
19\end{array}$ & $\begin{array}{l}30 \% \\
51 \% \\
19 \%\end{array}$ \\
\hline $\begin{array}{l}\text { Years of Computer Use: } \\
\text { Less than } 1 \text { year } \\
1-2 \text { years } \\
3-4 \text { years } \\
\text { Above } 4 \text { years }\end{array}$ & $\begin{array}{c}3 \\
13 \\
25 \\
40\end{array}$ & $\begin{array}{c}3.7 \% \\
16 \% \\
30.8 \% \\
49.3 \%\end{array}$ \\
\hline $\begin{array}{l}\text { Access to Computer: } \\
\text { Faculty Library } \\
\text { Faculty e-learning Centre } \\
\text { Home } \\
\text { Internet Café }\end{array}$ & $\begin{array}{l}- \\
- \\
12 \\
69\end{array}$ & $\begin{array}{c}- \\
- \\
15 \% \\
85 \%\end{array}$ \\
\hline $\begin{array}{l}\text { Access to Internet: } \\
\text { Yes } \\
\text { No }\end{array}$ & $\begin{array}{l}69 \\
12\end{array}$ & $\begin{array}{l}85 \% \\
15 \%\end{array}$ \\
\hline Frequency of Internet Use: & & \\
\hline $\begin{array}{l}\text { Never } \\
\text { Once a week }\end{array}$ & $\begin{array}{l}12 \\
31\end{array}$ & $\begin{array}{l}14.8 \% \\
38.3 \%\end{array}$ \\
\hline $\begin{array}{l}\text { Several times a week } \\
\text { Daily }\end{array}$ & $\begin{array}{l}23 \\
15\end{array}$ & $\begin{array}{l}28.4 \% \\
18.5 \%\end{array}$ \\
\hline
\end{tabular}




\begin{tabular}{lcc}
\hline Use of Emails: & & \\
Never & 27 & $33.3 \%$ \\
A few times a year & 13 & $16 \%$ \\
Monthly & 16 & $19.7 \%$ \\
Weekly & 20 & $24.7 \%$ \\
Daily & 5 & $6.2 \%$ \\
\hline
\end{tabular}

\section{Perceived ICT Competencies of Students}

Students perceived ICT competencies were examined using the ICT competency subscale in section $\mathrm{C}$ of the questionnaire. The subscale includes competencies on a basic suite of ICT applications which comprise of file navigation, word processing, email, and Internet. The participants were requested to rate their level of competency on a 5-point Likert-type scale; 5 for excellent, 4 for good, 3 for fair, 2 for low capability, and 1 for no capability. Table 3 presents the perceived ICT competencies of students.

Table 3: Perceived ICT Competencies of Students

\begin{tabular}{lccccc}
\hline \multirow{2}{*}{\multicolumn{1}{c}{ ICT Applications }} & \multicolumn{5}{c}{ Perceived Level of Competency } \\
\cline { 2 - 6 } & Excellent & Good & Fair & $\begin{array}{c}\text { Low } \\
\text { Capability }\end{array}$ & $\begin{array}{c}\text { No } \\
\text { Capability }\end{array}$ \\
Word Processing & $9 \%$ & $55 \%$ & $11 \%$ & $6 \%$ & $19 \%$ \\
\hline File Navigation & $9 \%$ & $42 \%$ & $25 \%$ & $5 \%$ & $19 \%$ \\
\hline Internet Browsing & $9 \%$ & $33 \%$ & $18 \%$ & $9 \%$ & $31 \%$ \\
\hline Emailing & $11 \%$ & $33 \%$ & $16 \%$ & $9 \%$ & $31 \%$ \\
\hline Presentation Tools & $2 \%$ & $8 \%$ & $9 \%$ & $11 \%$ & $70 \%$ \\
\hline
\end{tabular}

Table 3 shows that students perceived themselves to be competent (either excellent or good) in the use of word processing (64\%) and in file navigation (51\%). A lower proportion of respondents perceived themselves to be broadly good in Internet browsing (40\%) and emailing (42\%). As shown in Table 3also, 31\% of the respondents had no capability at all in Internet browsing and emailing. This is not surprising as Table 2 revealed that students' access to the Internet is mainly at cyber cafes, which means at their personal expense. An alarming scenario is presented in the table where $70 \%$ of the respondents have no capability at all in the use of presentation tools (PowerPoint). Only two percent (2\%) of the respondents considered themselves to be excellent in the use of PowerPoint. This should be expected as students would definitely not have seen their teachers make use of PowerPoint for as revealed in Table 2 students and faculty/staff have no access to computer in the faculty.

\section{The Effects of Demographic and Study Related Characteristics on Students' Perceived ICT Competencies}

A third issue investigated in this study is the differences in students' perceived ICT competencies in relation to gender, academic year/level, and type of computer training. Not much was found in the literature on academic year/level and ICT competencies. For this purpose ANOVA and Post Hoc tests were conducted, using an overall score for perceived ICT competencies which was calculated by summing the individual scores for each of the applications listed in Table 3 . The de- 
scriptive statistics of perceived ICT competencies in relation to demographic and study related variables are shown in Table 4.

Table 4: Descriptive Statistics of Perceived ICT Competencies in Relation to Demographic and Study-related Characteristics

\begin{tabular}{llll}
\hline \multicolumn{1}{c}{ Characteristics } & N & Mean & SD \\
\hline GENDER & & & \\
Male & 41 & 12.830 & 5.506 \\
Female & 59 & 12.083 & 5.977 \\
ACADEMIC YEAR/LEVEL & & & \\
200 Level & 24 & 12.431 & 5.278 \\
300 Level & 27 & 11.589 & 5.707 \\
400 Level & 49 & 13.351 & 5.842 \\
COMPUTER TRAINING & & & \\
None & 19 & 5.526 & 1.645 \\
Nonformal & 51 & 14.549 & 4.272 \\
Formal & 30 & 18.100 & 4.302 \\
\hline
\end{tabular}

Table 4 reveals that the means of the males (12.830) is higher than that of the females (12.083). While for the academic year/level the mean of those in 400 level (13.351) is the highest and for computer training those with formal computer training have the highest mean (18.100). To determine if the differences in means were significant a 3-way Analysis of Variance (ANOVA) was conducted. Table 5 presents the ANOVA results. There was main significant effect from computer training. The other two main effects of gender and academic year/level did not reach a significant level.

Table 5: Main and Interaction Effects of Demographic and Study Related Characteristics on Perceived ICT Competencies

\begin{tabular}{|l|r|r|r|r|r|}
\hline \multicolumn{1}{|c|}{ Source } & $\begin{array}{c}\text { Type III Sum of } \\
\text { Squares }\end{array}$ & \multicolumn{1}{c|}{$\begin{array}{c}\text { Mean } \\
\text { Square }\end{array}$} & \multicolumn{1}{c|}{$\mathrm{F}$} & Sig \\
\hline Sex & 8.800 & 1 & 8.800 & .561 & .456 \\
Academic Level & 35.120 & 2 & 17.560 & 1.119 & .332 \\
Computer Training & 1336.379 & 2 & 668.189 & 42.568 & .000 \\
Sex * Academic Level & 12.397 & 2 & 6.198 & .395 & .675 \\
Sex * Computer Training & 14.864 & 2 & 7.432 & .473 & .625 \\
Acad. Level * Comp. Training & 32.589 & 4 & 8.147 & .519 & .722 \\
Sex * Acad. Level * Comp.Trng. & 53.080 & 4 & 13.270 & .845 & .500 \\
Error & 1287.161 & 82 & 15.697 & & \\
Total & 22702.000 & 100 & & & \\
& & & & & \\
\hline
\end{tabular}




\section{Gender}

The F-value for gender in Table 5 is .561 with $\mathrm{df}=(1,82)$ significant at .456 , thus not significant at .05 level. It therefore indicates that there is no significant effect of gender on perceived ICT competencies scores. As presented in Table 4, the perceived ICT competencies mean of the males $(M=12.830)$ is higher than that of the females $(M=12.083)$, however, this difference is not significant enough to conclude that males perceive themselves to be more competent ICT users than the females.

\section{Academic year/level}

The F-value for academic year/level in Table 5 is 1.119 with $\mathrm{df}=2,82$ ) significant at .332 , thus not significant at .05 level. It therefore indicates that there is no significant effect of academic year/level on perceived ICT competencies scores.

\section{Computer training}

Table 5 shows that the F-value for computer training is 42.568 with $\mathrm{df}=(2,82)$ significant at .000 , which is significant at .05 level. It therefore indicates that computer training received by the student exerted a significant effect on perceived ICT competencies scores. To determine which type of training was most effective, a follow-up post-hoc analysis was conducted using Scheffe Multiple Comparison since the number of subjects in the three groups $(19,51,30)$ were unequal. The result is summarized in Table 6 .

Table 6: Post Hoc Analysis of Direction of Significance Using Scheffe Test

\begin{tabular}{|c|c|c|c|c|c|c|}
\hline \multirow{2}{*}{$\begin{array}{l}\text { (I) } \\
\text { Computer } \\
\text { Training }\end{array}$} & \multirow{2}{*}{$\begin{array}{l}\quad(\mathrm{J}) \\
\text { Computer } \\
\text { Training }\end{array}$} & \multirow[b]{2}{*}{$\begin{array}{l}\text { Mean Dif- } \\
\text { ference } \\
(I-J)\end{array}$} & \multirow[b]{2}{*}{ Std. Error } & \multirow[b]{2}{*}{ Sig. } & \multicolumn{2}{|c|}{ 95\% Confidence Interval } \\
\hline & & & & & $\begin{array}{l}\text { Lower } \\
\text { Bound }\end{array}$ & $\begin{array}{l}\text { Upper } \\
\text { Bound }\end{array}$ \\
\hline \multirow[t]{2}{*}{ Nonformal } & Formal & $-3.5510^{*}$ & .91160 & .001 & -5.8237 & -1.2782 \\
\hline & None & $9.0227^{*}$ & 1.06487 & .000 & 6.3678 & 11.6776 \\
\hline \multirow[t]{2}{*}{ Formal } & Nonformal & $3.5510^{*}$ & .91160 & .001 & 1.2782 & 5.8237 \\
\hline & None & $12.5737^{*}$ & 1.16164 & .000 & 9.6776 & 15.4698 \\
\hline \multirow[t]{2}{*}{ None } & Nonformal & $-9.0227^{*}$ & 1.06487 & .000 & -11.6776 & -6.3678 \\
\hline & Formal & $-12.5737^{*}$ & 1.16164 & .000 & -15.4698 & -9.6776 \\
\hline
\end{tabular}

As indicated in Table 6 there are significant differences among the three groups.

\section{Discussion}

This study examined the ICT usage habits and perceived ICT competencies of undergraduate students in teacher preparation programmes in the University of Benin. Another important issue was to determine whether there were differences in the perceived ICT competencies according to demographic and study related variables. Respondents were asked questions relating to computer literacy, computer knowledge, use of ICT skills, form of computer training, access to infrastructures such as computers and the Internet, and frequency of Internet and email usage. The results showed a low level of ICT usage. These findings are broadly in agreement with findings from 
studies on the level of computer literacy in Nigerian universities (Adomi \& Anie, 2006; Asogwa, 2006; Bassey et al., 2007). While it is recommended that students entering the undergraduate programmes in Nigerian universities be computer literate, as most of the administrative processes (e.g. course registration, payment of fees, booking of hostel accommodation, etc.) are done online, it has not yet been made a mandatory requirement of entry on the basis of equity and access.

The lack of access to the Internet on campus is not in line with the vision of the U B Technologies initiatives, which was meant to provide access to computer workstations and the Internet for a token fee. The use of cybercafés presents another dimension to the use of the computer/Internet, as the findings revealed that most of the "computing" time is spent partaking in a variety of online activities such as web surfing, as opposed to more "traditional" computing activities like word processing. This result aligns well with a common theme in computer education literature, which suggests that while social or recreational use of computers is high, the more academic use is seen as boring and only undertaken when really necessary.

There are important considerations in the use of the Internet by students that go beyond mere access to computing facilities and the Internet. Even when every student is "online", not all of them may have the same type of connections. Some may have the benefit of high speed, dedicated networking, whereas the only option for some students may be a dialup modem line that does not support the data transfer rate required for high quality interactive multimedia programmes (Ingram, 1996). Additionally, simply having the requisite computer resources does not automatically grant access to the information highway. If one is unfamiliar with computers or the Internet, attempting to navigate this new medium can be frustrating and frightening. This confirms Brogan's (1997) findings, which found that 75 percent of all students in his study indicated the need for training in the use of the Internet.

With respect to perceived ICT competencies, the analysis of the data revealed that overall students did not perceive themselves very competent in ICT. However, the self-assessment by respondents as to their level of competency may be somewhat subjective, as perception of knowledge and ability in computer skills do not always correspond to the reality (Ballantine, McCourt, \& Cyelere, 2007). The result is in line with findings with Nigerian university students reporting themselves as knowing how to use the Internet (Adomi \& Anie, 2006; Asogwa, 2006; Bassey et al., 2007). Students' patronage of Internet cafes might be the result of their level of competency in the use of word processing and file navigation applications. This however, is not an encouraging level of competency if students are to benefit from e-learning. In general, the results for competency in Internet browsing and emailing revealed ratings between the ranges of "fair" and "good," that is a moderate level of skills in these applications. For competency in the use of presentation tools, respondents' results revealed that only a negligible percentage of the respondents have competency in this ICT application. Overall, the results are consistent with the literature that there is dire need to improve and facilitate the innovative use of technology and embed technology usage in higher education curriculum in the country (Adomi \& Anie, 2006; Asogwa, 2006; Bassey et al., 2007).

The findings indicate that there is no significant difference between male and female in their perceived ICT competencies. This is not surprising as studies have shown that gender gap in ICT usage is gradually closing up, especially among students in tertiary institutions as evident in that of Ozoemelen (2010) who found out that the gender gap in Internet use has narrowed significantly in the college age group. However, the finding is at variance with that of Ono and Zavodny's (2003) study which found females to be less frequent and intense users of the Internet. There was similarly no significant difference among students according to academic year/level. The findings indicate that there is significant difference in the perceived ICT competencies of the students who had taken computer courses. Altan (2003) found a similar result which suggests that 
there is a significant difference between those who have taken a computer course and those who have not.

\section{Limitations of the Study}

It should be noted that the study presented here has several limitations. The sample size of one hundred (100) students of the five departments in the Faculty of Education at the University of Benin will make generalization difficult. Furthermore, the use of perception to find out skill competency is a limitation as students might not be truthful in reporting their level of competency. Making them carry out these practical skills would have been a better option.

\section{Conclusion}

The findings of this study showed a low level of ICT usage by the respondents. The lack of access to computers and Internet connectivity within the faculty is worrisome. From the findings, it is clear that the critical factor of institutional provision of ICT infrastructure has not yet been reached. One not only needs the infrastructure available, but also the personal skills in order to use ICT. It is evident from the literature that unless the issue of ICT competency is addressed, it can itself be a barrier to students' learning. We suggest that special funds be created to revamp the e-learning support centres at the faculty level for students and faculty/staff use. Regarding future research, further studies utilizing random sampling technique should be designed to increase the generalizability of these findings. Further studies employing the use of interviews or observations would generate a fuller understanding of our reported survey results.

\section{References}

Adomi, E. E., \& Anie, S. O. (2006). An assessment of computer literacy skills of professionals in Nigerian university libraries. Library HiTech News, 23(2), 10- 14.

Altan, A. (2003).The relationship between teacher trainee's attitudes towards computers and their cognitive styles. The Turkish Online Journal of Educational Technology, 2(1), Article 9.

American Association of University Women (AAUW). (2004). Educating girls in the new computer age. New York: AAUW Educational Foundation Tech Savvy.

Asogwa, U. D. (2006). E-learning: A panacea for access, equity and quality higher education in Nigeria. Paper presented at the 30th Annual conference of Nigerian Association for Educational Administration and Planning (NAEAP) held at the Faculty of Education Hall, Enugu State University of Science and Technology, Enugu, Nigeria. 2-3 October 2006.

Atan, H., Azli, N., Rahman, Z., \& Idrus, R. (2002). Computers in distance education: Gender differences in self-perceived computer competencies. Journal of Educational Media 27(3), 123-135.

Ballantine, J., McCourt Larres, P., \& Cyelere, P. (2007). Computer usage and the validity of self-assessed computer competence among first year business students. Computers and Education, 49, 976 - 990

Bassey, U. U., Akuegwu, B. A., Udida, L. A., Ntukidem, E. P., \& Ekabua, O. O. (2007). Nigerian graduating students' access to e-learning technology: Implications for higher education management. ICTLearn2007, $6^{\text {th }}$ International Internet Education Conference. Egypt 2-4 September 2007. Ramses Hilton: Cairo.

Bebetsos, E., \& Antoniou, P. (2008).University students' differences on attitudes towards computer use: Comparison with students' attitudes towards physical activity. Interactive Educational Multimedia, 17, 20-28. Retrieved $15^{\text {th }}$ August 2012 from http://greav.ub.edu/iem/index.php?

Brogan, M. (1997). Off-campus and off-line? Access to the Internet of postgraduate TESOL students at Deakin University. In T. Evans \& V. Jakupec \& D. Thompsons (Eds). Research in Distance Education 
4: Revised papers from the Fourth Research in Distance Education conference, Deakin University, 115-117

Casal, R. C. (2007). ICT for education and development. Info, 9(4), 3-9.

Cheetham, G., \& Chivers, G. (2001). How professionals learn in practice: An investigation of informal learning amongst people working in professions. Journal of European Industrial Training, 25(5), 248292.

Commonwealth Department of Education, Science and Training. (2002). Striving for quality: Learning, teaching and scholarship. Canberra.

Department for Education and Employment (DfEE). (2000). Press Release 34/00(31/01/00). End the digital divide -Wills. Retrieved from http://www.dfes.gov.uk/pns/DisplayPN.cgi?pn_id=2000_0034

Derbyshire, H. (2003). Gender issues in the use of computers in education in Africa. Retrieved $15^{\text {th }}$ August 2012 from http://www.enawa.org/icons/Tekstbestanden/Gender\%20Report\%20the\%20

Federal Ministry of Education. (2010). National policy on information and communication technologies (ICT) in education. Abuja: Federal Ministry of Education.

Hughes, M. M. (2005). Reach to teach ICT: Issues and compromises. Education and Information Technologies, 10(3), 263-276.

Ingram, A. L. (1996). Teaching with technology. Association Management, 44(6), 38-47.

Jegede, P. O. (2008). Attitudinal characteristics and use level of Nigerian teachers. Issues in Informing Science and Information Technology, 5, 261-266. Retrieved 15 August 2012 from http://proceedings.informingscience.org/InSITE2008/IISITv5p261-266Jegede533.pdf

Jegede, P. O. (2009). Assessment of Nigerian teacher educators' ICT training. Issues in Informing Science and Information Technology, 6, 415-420. Retrieved from http://iisit.org/Vol6/IISITv6p415420Jegede639.pdf

Kadel, R. (2005). How teacher attitudes affect technology. Learning and Leading with Technology, 39 (5), 34-47.

Kay, R. H. (2006). Evaluating strategies used to incorporate technology into pre-service education: A review of the literature. Journal of Research in Technology in Education, 38(4), 383-408.

Kirschner, P., \& Woperies, I. G. (2003). Pedagogic benchmarks for information and communication technology in teacher education. Technology, Pedagogy and Education, 12(1), 127-149.

Koehler, M. J., Mishra, P., \& Yahya, K. (2007).Tracing the development of teacher knowledge in a design seminar: Integrating content, pedagogy, and technology. Computers and Education, 49, 740-762.

Kumar, P., \& Kumar A. (2003).Effect of a web-based project on preservice and in-service teachers' attitudes toward computers and technology skills. Journal of Computing in Teacher Education, 19(3), 8792.

Lee, D. (1997). Factors influencing the success of computer skills learning among in-service teachers. British Journal of Educational Technology, 28, 139-141.

Marija, B., \& Palmira, P. (2007). Would-be teachers' competence in applying ICT: Exposition and preconditions for development. Informatics in Education - An International Journal, 6(2), 397-410.

Meelissen, M. R. (2005). ICT: More for Mickey than for Minnie? The role of primary education in making information and communication technology more attractive for girls and boy., Doctoral dissertation, University of Twente, Enschede, The Netherlands.

Murray, S., Nuttall, J., \& Mitchell, J. (2008). Research into initial teacher education in Australia: A survey of the literature 1995 - 2004. Teaching and Teacher Education, 24(10), 225-239. 
Nash, J. (2009). Computer skills of first-year students at a South African university. Proceedings of the 2009 Annual Conference of the Southern African Computer Lecturers' Association, Eastern Cape, South Africa (SACLA '09), Mpekweni Beach Resort, South Africa, June 29-July 01, 2009.

Olakulehin, F. K. (2007). Information and communication technologies in teacher training and professional development in Nigeria. Turkish Online Journal of Distance Education, 8(1), 133-142.

Oliver, R. (1993). A comparison of students' information technology skills in 1985 and 1991. British Journal of Educational Technology, 24(1), 52-62.

Oliver, R. (2002). The role of ICT in higher education for the 21 st century: ICT as a change agent for education. Retrieved 15 August 2012 from http://elrond.scam.ecu.edu.au/oliver/2002/he21.pdf

Ololube, N. P. (2007). The relationship between funding, ICT, selection processes, administration, planning and the standard of science teacher education in Nigeria. Asia-Pacific Forum on Science Learning and Teaching, 8(1), 1-29. Retrieved 15 August 2012 from http://www.ied.edu.hk/apfslt/v8 issue1/ololube/index.htm\#abstrac

Ono, H., \& Zavodny, M. (2003). Gender and the Internet. Social Science Quarterly, 84(1), 111-121.

Ozoemelem, O. A. (2010). Web affinity: A study of undergraduate students in Nigerian universities. Library Philosophy and Practice [e-journal]. Retrieved on $15^{\text {th }}$ April 2012 from http://www.webpages.uidaho.edu/ mbolin/obuh2.htm

Rajagopal, I., \& Bojin, N. (2003). A gendered world: Students and instructional technologies. First Monday 8(1), Retrieved on $15^{\text {th }}$ April 2012 from http://firstmonday.org/htbin/cgiwrap

Robbins, V. (1998). The development of information technology skills in trainee teachers for further education sector. Research in Post-Compulsory Education, 3(2), 240-251.

Ryan, J., \& Scott, A. (2008). Integrating technology into teacher education: How online discussion can be used to develop informed and critical literacy teachers. Teaching and Teacher Education, 24(6), 1635 -1644 .

Schaumburg, H. (2001). Fostering girls' computer through laptop learning - Can mobile computers help to level out the gender difference? Retrieved 12 August 2012 from http://www.notesys.com/Copies/necc01.pdf

Sefyrin, J. (2005). Understandings of gender and competence in ICT. In A. Archibald, J. Emms, F. Grundy, J. Pagne \& E. Turner (Eds). The gender politics of ICT (pp. 95-106). London: Middlesex University Press.

TengkuFaekah, T. A. (2005). Gender differences in computer attitudes and skills. Journal Pendidikan, 30, 75-91.

UNESCO. (2008). ICT Competency standards for teachers: Policy framework. Retrieved on $11^{\text {th }}$ April 2012 from http://unesdoc.unesco.org/images/0015/001562/156210E.pdf

Watson, M. D. (2005). Pedagogy before technology: Re-thinking the relationship between ICT and Teaching. Education and Information Technologies, 6(4), 252-266.

Western Australian Guide. (2003). Teaching and learning with ICT: A self-evaluation guide. Western Australia: Department of Education and Training.

White, G. (2003). E-learning: Key Australian initiatives (An opportunity for all learners). Retrieved on $15^{\text {th }}$ April 2012 from http://www.educationau.edu.au/papers/elearning_polaand03.pdf

Yusuf, M.O. (2005). Information and communication technology and education: Analysing the Nigerian national policy for information technology. International Education Journal, 6(3), 316 - 321. 


\section{Biographies}

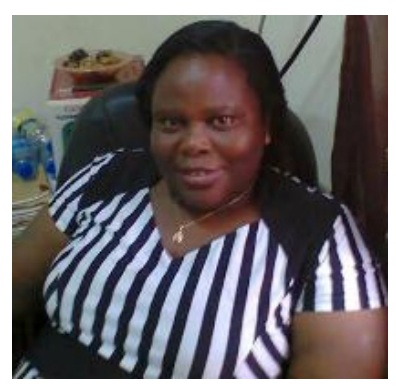

Regina Danner holds a $\mathrm{PhD}$ in Language Education (English) from the University of Benin, Benin City, Nigeria. She is a lecturer in the Department of Educational Psychology and Curriculum Studies, University of Benin. Her areas of research interest include instructional methods in English Grammatical Structures, Reading and the use of Information and Communication Technologies (ICTs) in Education. She has presented papers in national and international conferences on ICTs in education. Before her present appointment, Dr Danner was a chief examination Officer with the National Business and Technical Examinations Board, Benin City. She is a member of the International Reading Association (IRA).

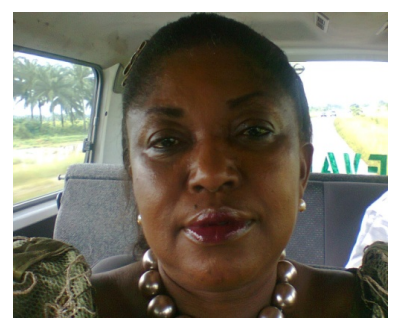

Clara Pessu holds a B.Ed in English Language and Literature, M.Ed and Ph.D in Educational Planning from the University of Benin, Benin City, and currently the Vice-principal in Girls' Model Secondary School, Evwreni, Delta State, Nigeria. Prior to her appointment as Vice-principal, she taught English Language and Literature-in-English in senior secondary schools across the state. Her area of research interests include Teacher Improvement and use of ICTs in Education and has functioned as centre coordinator at Teacher Capacity Building Workshops organized by Delta state government. Dr Pessu is a member of the International Reading Association (IRA) and the Nigerian Association for Educational Administration and Planning (NAEAP). 